\title{
Water Harvesting: A Source of Livestock Water
}

\section{GARY W. FRASIER}

Highlight: Water harvesting is a means of supplying stockwater in any area where precipitation is sufficient to grow forage. There are many types of methods and materials which can be used to collect precipitation. Knowledge of the advantages and disadvantages of each treatment is needed to select the method best suited for a given site. Costs of water collected from various treatments range from less than $\$ 0.20$ per 1,000 gallons to over $\$ 6.00$ per 1,000 gallons in a 20-inch precipitation zone.

In many areas of our western rangelands, stockwater can be supplied by a method called water harvesting using structures called trick tanks, rain traps, or catchments to collect and store precipitation runoff. Properly designed water harvesting systems are potentially capable of supplying stock drinking water in any area where there is sufficient precipitation to grow forage. In many places, water harvesting is less costly than alternate means such as hauling or piping.

\section{Water Harvesting Methods}

Water harvesting techniques can be divided into five basic methods: (1) vegetation management, (2) natural impervious surfaces, (3) land alteration, (4) chemical treatment of the soil, and (5) ground covers. These methods have a wide range of costs, performance, and durability, which can limit the potential applicability of a treatment (Cooley et al., 1970). Knowledge of the advantages and disadvantages of each method or treatment is needed to select the treatment best suited for a given site.

\section{Vegetation Management}

Studies have shown that in some areas, surface runoff can be increased by converting scrub woodland to a grass forage cover (Gifford, 1973). In many places, this method cannot be used as a source of livestock water because of the necessity of constructing major dams or diversion structures in the watershed drainage channel. For some limited locations, it may be possible to collect the runoff water before it reaches the main channel.

\section{Natural Surfaces}

The simplest and probably the most durable material for a catchment surface is a large rock outcropping (Fig. 1). Usually all that is necessary to convert the outcropping into a suitable

The author is research hydraulic engineer, U.S. Water Conservation Laboratory, Phoenix, Arizona 85040.

The paper was presented at the 27th Annual Meeting, Society for Range Management, February 3-8, 1974, Tucson, Arizona, under the title "Water Harvesting for Range Management," by Gary Frasier. Contribution from the Agricultural Research Service, U.S. Department of Agricult ure.

Manuscript received September 28, 1974. catchment are some small diversion dikes along the lower edge which direct the runoff water into the storage facility. Runoff efficiencies from natural rock surfaces are variable, depending upon the porosity of the base rock and the number and extent of cracks in the surface. Burdass (1975) reported that in Australia, the common practice is to use $45 \%$ as the runoff efficiency for rock catchments. On some rock surfaces, the runoff efficiency can be improved by sealing the surface cracks with an asphaltic caulking compound. In some areas, it is possible to compensate for the relatively low runoff efficiency by simply increasing the size of the collection area. Total costs for preparing a rock catchment may be as low as $\$ 0.01$ per square yard of collecting area (Table 1).

The highways and roads which cross the rangelands can also be used for collecting precipitation (Fig. 2). The full potential of using highways for water harvesting has not been realized because of the concern that the runoff water could be contaminated by oil droppings from the vehicular traffic. Chiarella and Beck (1975) describe a highway catchment system in Arizona used for collecting drinking water for livestock for over 15 years with no observed ill effects. Evans et al. (1975) reported that in Wyoming there are approximately 8 acres of pavement per mile of interstate highway. If we assume a catchment efficiency of $90 \%$, a potential water supply of about 2 million gallons of water is available per mile of highway for every 10 inches of precipitation. The major cost of collecting this water is the expense of a conveyance system from the highway to the storage.

\section{Land Alteration}

For the thousands of acres of land where highways or rock outcropping are not available, a livestock water supply can sometimes be developed by simple land alteration treatments which increase the quantity of runoff from the soil surface. Land clearing is the least expensive method of land alteration, but the increase in precipitation runoff is often negligible except for storms of high precipitation intensity and/or long duration. Because the small precipitation events do not always produce satisfactory runoff, it is usually necessary to have relatively large catchment areas and storage structures to provide adequate water to last between the runoff events.

On some soils, the runoff efficiency from land clearing treatments can be effectively increased by additional soil smoothing and/or soil compaction. Land alteration, soil smoothing, and compaction is presently used successfully in Australia in the form of roaded catchments (Frith, 1975). Soil smoothing and compacting treatments are usually more successful on loam or clay loam soils. Care must be taken in the design and construction of this type of treatment to minimize the soil slope and runoff water velocity to reduce any potential soil erosion (Hollick, 1975). 


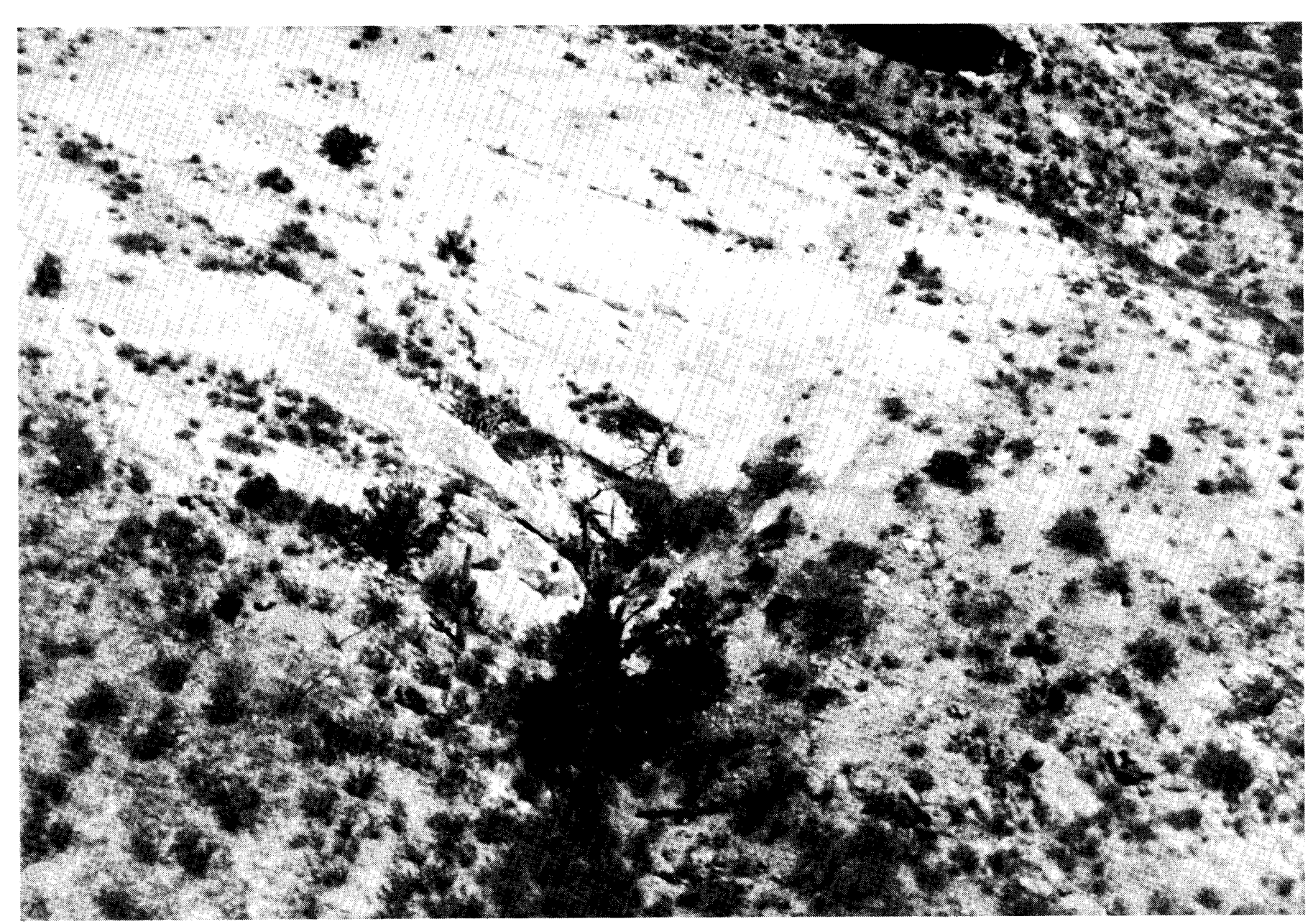

Fig. 1. Large rock outcropping used as a water harvesting catchment.

\section{Chemical Soil Treatments}

On some soils it is possible to apply chemicals which induce a water repellency to the soil surface. The water-repellent soil surface reduces or stops infiltration, thereby increasing the quantity of runoff water. On a loamy sand soil in southern
Arizona, a plot treated with a silicone water repellent yielded over 90-percent runoff during the first year (Myers and Frasier, 1969). Four years later, runoff had declined to about $60 \%$ as the treatment gradually deteriorated. Silicone-treated catchments may be damaged by erosion because of insufficient

Table 1. Water costs for various water harvesting treatments.

\begin{tabular}{|c|c|c|c|c|c|}
\hline Treatment & $\begin{array}{c}\text { Runoff } \\
(\%)\end{array}$ & $\begin{array}{c}\text { Estimated } \\
\text { life of } \\
\text { treatment } \\
\text { (years) }\end{array}$ & $\begin{array}{c}\text { Initial } \\
\text { treatment } \\
\text { cost } \\
\left(\$ / \mathrm{yd}^{2}\right) \\
\end{array}$ & $\begin{array}{c}\text { Annual } \\
\text { amortized } \\
\text { cost }^{1} \\
\left(\$ / \mathrm{yd}^{2}\right) \\
\end{array}$ & $\begin{array}{c}\text { Water cost } \\
\text { in a } 20 \text {-inch } \\
\text { rainfall zone } \\
(\$ / 1,000 \text { gal })\end{array}$ \\
\hline Rock outcropping & $20-40$ & $20-30$ & $<0.01$ & $<0.02$ & $0.22-0.45$ \\
\hline Land clearing & $20-30$ & $5-10$ & $0.01-0.02$ & $<0.01$ & $0.30-0.45$ \\
\hline Soil smoothing & $25-35$ & $5-10$ & $0.05-0.07$ & $0.01-0.02$ & $0.25-0.71$ \\
\hline Sodium dispersan $t^{2}$ & $40-70$ & $3-5$ & $0.07-0.12$ & $0.01-0.02$ & $0.13-0.45$ \\
\hline Silicone water repellents ${ }^{3}$ & $50-80$ & $3-5$ & $0.12-0.18$ & $0.02-0.04$ & $0.22-0.71$ \\
\hline Paraffin $w^{4}{ }^{4}$ & $60-90$ & $5-8$ & $0.30-0.40$ & $0.05-0.10$ & $0.50-1.49$ \\
\hline Concrete & $60-80$ & 20 & $2.00-5.00$ & $0.17-0.44$ & $1.89-6.53$ \\
\hline Gravel covered membranes & $70-80$ & $10-20$ & $0.50-0.70$ & $0.04-0.10$ & $0.45-1.27$ \\
\hline Asphalt fiberglass ${ }^{5}$ & $85-95$ & $5-10$ & $1.00-2.00$ & $0.14-0.48$ & $1.31-5.00$ \\
\hline Artificial rubber 6 & $90-100$ & $10-15$ & $2.00-3.00$ & $0.21-0.41$ & $1.87-4.00$ \\
\hline Sheet metal ${ }^{7}$ & $90-100$ & 20 & $2.00-3.00$ & $0.17-0.26$ & $1.51-2.57$ \\
\hline
\end{tabular}

\footnotetext{
${ }^{1}$ Based on the life of the treatment at $6 \%$ interest.
}

${ }^{2}$ Cluff, 1975.

${ }^{3}$ Myers and Frasier, 1969.

${ }^{4}$ Fink, et al., 1973.

${ }^{5}$ Myers and Frasier, 1974.

${ }^{6}$ Lauritzen and Thayer, 1966.

${ }^{7}$ Laurit zen, 1967. 


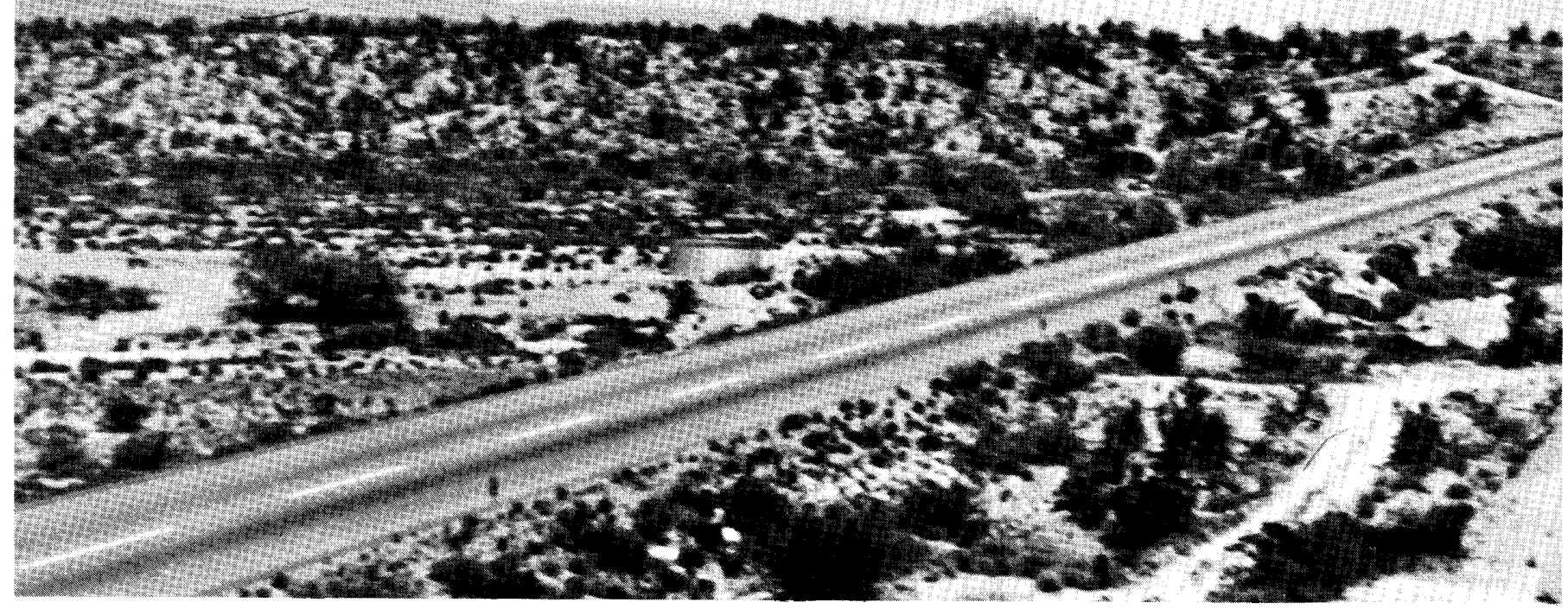

Fig. 2. Highway used as a livestock water catchment on San Carlos Indian Reservation in Arizona.

soil stabilization from the silicone treatment. Studies are being conducted to determine the possibility of adding a soil stabilizing compound to the silicone mixture to reduce soil erosion.

Recently, paraffin wax has been found to be effective in making soils water repellent (Fink et al., 1973) (Fig. 3). The paraffin wax treatment does partially stabilize the soil in addition to waterproofing the soil. Studies on a half-acre operational catchment treated with the paraffin wax indicate the treatment may lose its waterproofing ability, at least temporarily, if the soil freezes and thaws when there is a film of water on the soil surface. Subsequent studies with a laboratory freeze-thaw chamber confirmed the field data. These studies also showed the treatment effectiveness can be regenerated if the soil surface is reheated to a temperature above the melting point of the wax $\left(128^{\circ} \mathrm{F}\right.$ for the study). In many places, the surface soil temperatures will naturally exceed this temperature during warm summer days.

Another method of chemically reducing infiltration of water and increasing surface runoff is to disperse the clay in the soil to plug the soil pores. On some soils this can be accomplished by the application of a sodium salt such as

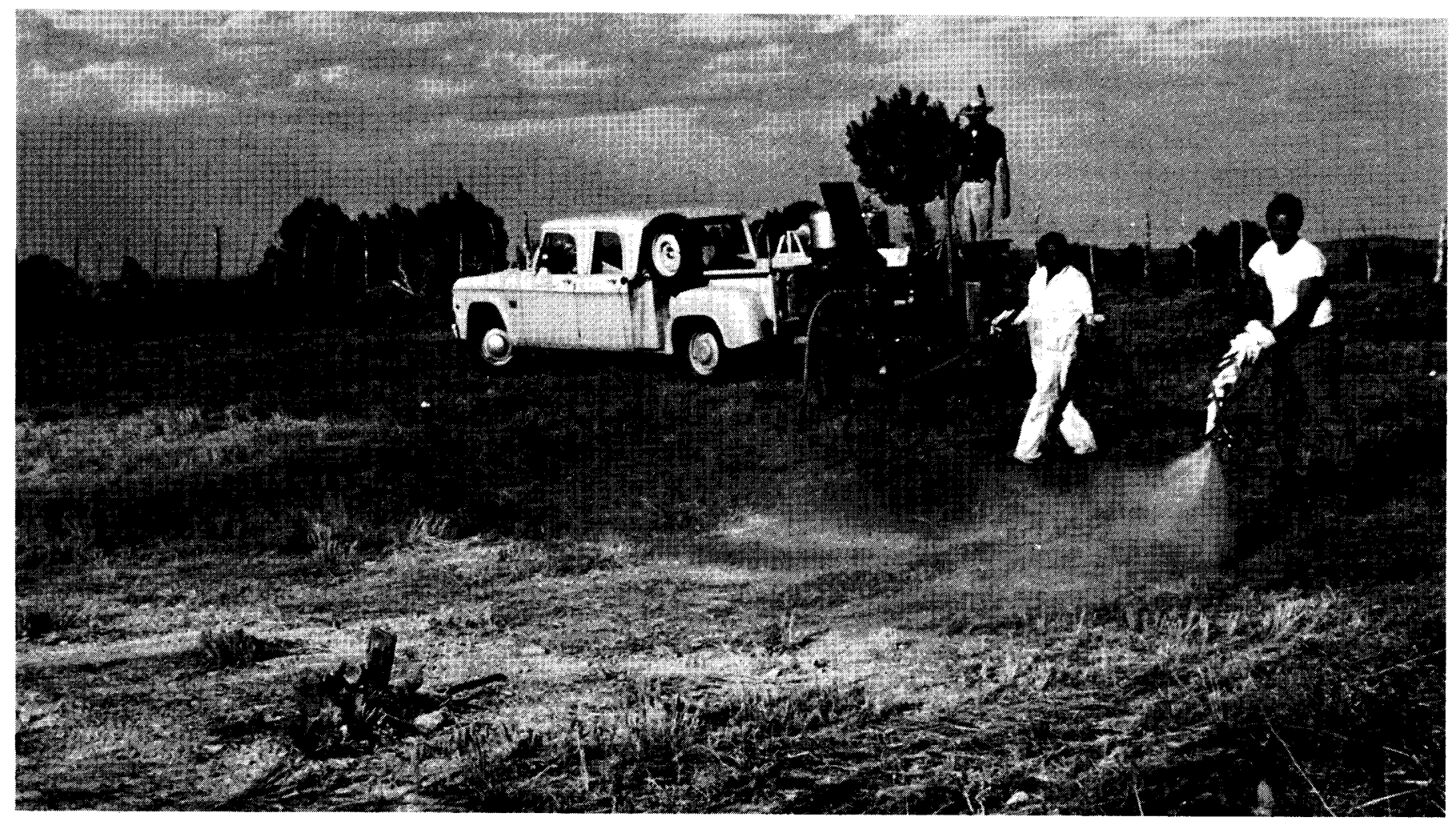

Fig. 3. Application of paraffin wax to a catchment on the San Carlos Indian Reservation in Arizona. 
sodium carbonate. This type of treatment has been very successful for sealing of stock tanks (Reginato et al., 1973) and shows promise of working on some catchment areas (Dutt and McCreary, 1975). A sodium salt treatment requires a minimum quantity of expanding type clay in the soil, and soil erosion is a potential problem.

\section{Ground Covers}

The remainder of the methods discussed for water harvesting are classified as ground covers. These are treatments where the soil surface is covered with some form of impermeable membrane.

Concrete has been used as a method of water harvesting for many years. Poured concrete slabs are quite durable but have the disadvantage of being relatively expensive and will crack from shrinkage unless properly designed expansion joints are provided. A simple and inexpensive method of sealing the cracks is to bond strips of fiberglass to the concrete over the cracks with an asphalt emulsion. Periodic maintenance and inspection will insure that the cracks will remain sealed. Even with sealed cracks, concrete will not yield 100-percent runoff because of a natural surface porosity that absorbs a measurable quantity of precipitation before runoff will occur (Frasier, 1975).

Gravel-covered membranes of various materials such as plastic or tar paper have been used as successful ground cover treatments (Cluff, 1967). The gravel covering reduces the deterioration of the impermeable plastic or paper membrane layer and provides some measure of protection from mechanical damage. The treatment is relatively easy to install and low cost if there is a source of clean gravel near the catchment site. Any damage to the membrane during the placement of the gravel can be serious if it occurs at a low spot in the catchment, but normal care during installation will usually suffice in insuring a satisfactory treatment. There is the possibility of plants growing on the gravel covering from windblown seeds if the gravel was not clean or if sufficient time has elapsed to permit dust to be deposited in the gravel layer. The gravel layer will retain a part of each rainfall event by retention. This retained water is then lost by evaporation into the air resulting in a reduced catchment efficiency (Frasier, 1975).

Ground covers of fiberglass or polypropylene matting saturated with asphalt are another durable method presently being used in various places for harvesting water (Myers and Frasier, 1974). The matting serves as a reinforcing fabric, and the asphalt is the waterproofing agent (Fig. 4). Application of protective paints to the surface of the covers reduces the problem of discolored runoff water from asphaltic surface and extends the time period between application of new seal coats (Frasier, 1970). Asphalt-fiberglass catchments have been successfully installed over surfaces too rough for the majority of membrane coverings. Although the rough surface retains some water, the membrane shows only minor deterioration after 5 years of use. Installation of asphalt-fiberglass catchments does require considerable labor.

Artificial rubber membranes have been used as water harvesting catchments for over 20 years at several locations in the United States (Lauritzen and Thayer, 1966) (Fig. 5). Correctly installed and maintained sheeting results in a good source of clean water. Many past failures of butyl catchments can be attributed to improper installation procedures, lack of maintenance, improper formulated material, or lack of

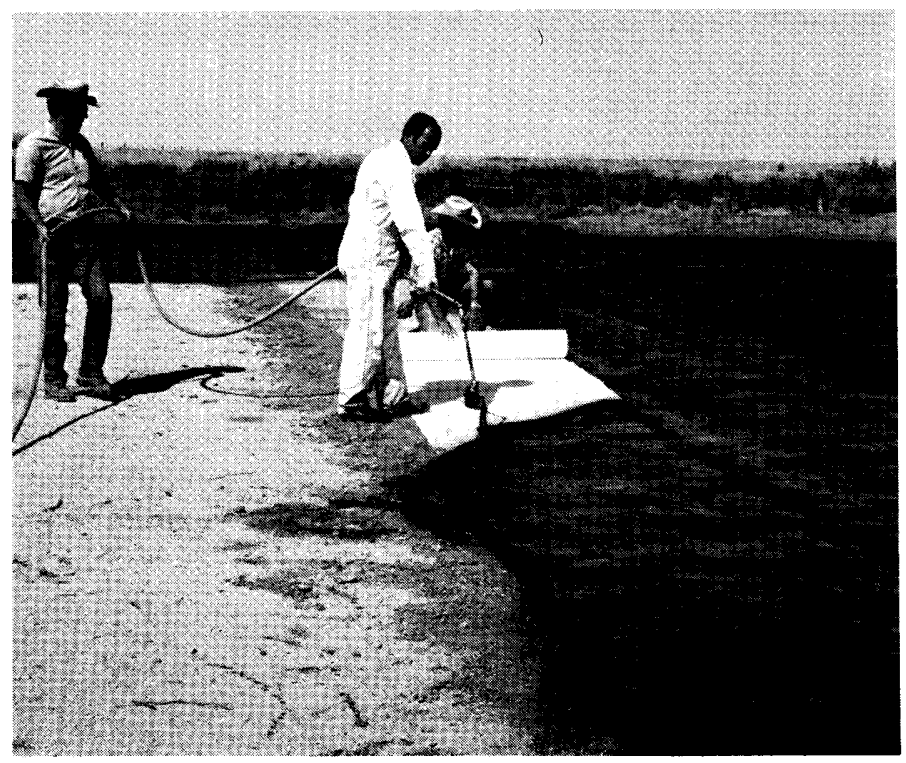

Fig. 4. Installation of an asphalt-fiberglass water harvesting catchment.

protection from animals or rodents (Dedrick, 1973). Artificial rubber catchments are one of the simplest ground covers to install after the catchment site has been properly prepared.

Sheet metal can be a very durable and effective catchment material. In the past, it was thought necessary to construct these catchments above ground on a framework similar to a roof of a building. The majority of these catchments performed satisfactorily until the support framework deteriorated and collapsed. Sheet metal catchments have been installed with the sheeting laid directly on the ground with a good undercoating of asphaltic paint to reduce corrosion (Fig. 6). Bolting the sheets into a continuous covering and adequate edge tiedowns are all that are required (Lauritzen, 1967).

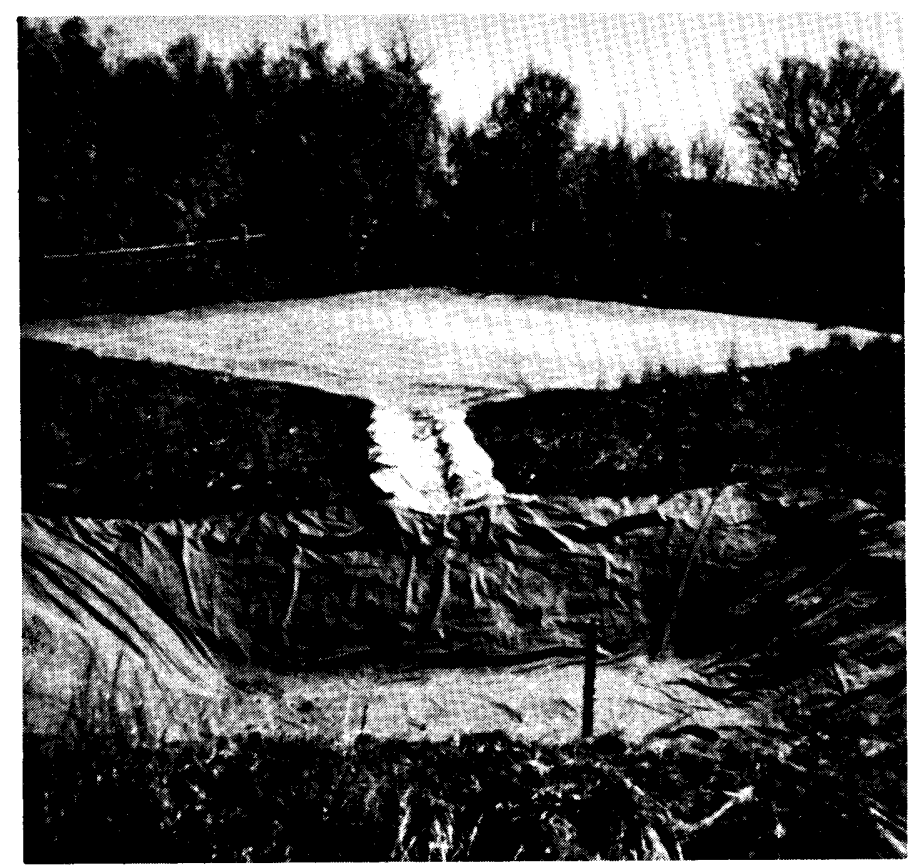

Fig. 5. Butyl rubber catchment. 
Table 2. Advantages and disadvantages of various types of storage structures for water harvesting systems.

\begin{tabular}{|c|c|c|}
\hline Storage method & Advantages & Disadvantages \\
\hline \multicolumn{3}{|l|}{ Excavated pits } \\
\hline \multirow[t]{2}{*}{ Unlined } & a) Low cost & a) May have excessive seepage losses \\
\hline & b) Allow direct animal access & b) Must have sufficient soil depth \\
\hline Chemically sealed & a) Low cost & a) Not suitable on all soil types \\
\hline & & b) Some materials unable to withstand wetting and drying \\
\hline Membrane linings & a) Eliminates all seepage losses & $\begin{array}{l}\text { a) High cost } \\
\text { b) Potential damage by livestock }\end{array}$ \\
\hline Tanks & a) Universally available & - a) High cost \\
\hline Bags & $\begin{array}{l}\text { a) Eliminates evaporative losses } \\
\text { b) Easily installed }\end{array}$ & $\begin{array}{l}\text { a) Damaged by rodents and livestock } \\
\text { b) Not suitable where snow drifts }\end{array}$ \\
\hline
\end{tabular}

\section{Water Storage}

A complete water harvesting system also includes some means of storing the collected water until it is needed (Dedrick, 1975). There are three basic ways of storing the water: (1) excavated pits, (2) above-ground tanks made from materials such as steel or wood, and (3) bags of plastic or rubber. Table 2 lists some of the methods which have been used for storing water and the advantages and disadvantages of each. The cost of constructing the water storage facility in remote sites is affected by the accessibility of the site for construction. On some sites the accessibility of men and equipment is the limiting factor in the selection of the water storage system.

\section{Maintenance}

Maintenance cost for a water harvesting system is highly variable. Not all catchment treatments require the same quantity and kind of maintenance. For the smoothed soil treatments, weed growth must be eliminated and soil erosion prevented. Chemical treatments require similar attention. Maintenance of ground cover treatments primarily consists of repair of mechanical damage to the materials. The storage system and conveyance system between catchment and storage must be included in a maintenance program. This type of maintenance would usually be able to be completed by one man spending approximately 1 to 2 hours at each water harvesting system about 4 times a year.

\section{Water Costs}

Runoff efficiency, initial costs, and amortized annual cost of the various treatments are shown in Table 1. The treatment life and runoff efficiencies are based on the results of 11 years of study at the Granite Reef test site and on 15 operational field units constructed in cooperation with private ranchers

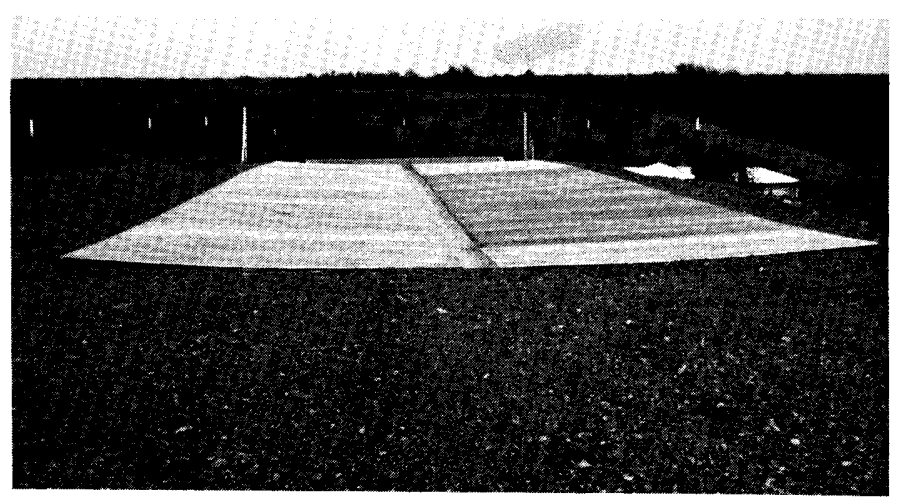

Fig. 6. Sheet metal catchment. and governmental agencies. Water costs, shown in the last column, are based on a total annual precipitation of 20 inches per year and an amortized annual cost of $6 \%$ interest for the expected life of the treatment. They do not include any yearly maintenance costs. Computed water costs varied from less than $\$ 0.20$ per 1,000 gallons for the sodium salt treatment to over $\$ 6.50$ per 1,000 gallons for a concrete catchment. These costs will vary according to the local availability of the various construction materials and the remoteness of the catchment site. They can be used for comparative purposes in the selection of the type of catchment and material during the initial design stages.

It must also be remembered that the total cost of water from a water harvesting system must also include the cost of storing the water. Storage costs are highly variable, depending upon the type and size of structure required. Catchments with lower runoff efficiencies will often require larger water storage facilities to insure adequate water when needed (Frasier, 1975).

\section{Conclusions}

Water harvesting is a means of potentially supplying stock drinking water in any area where there is sufficient precipitation to produce forage. Knowledge of the advantages and disadvantages of each of the many methods of water harvesting is needed to select the treatment best suited for a given site.

Large rock outcroppings and highways are potentially low-cost catchment surfaces which have not been utilized to full potential. Costs of water harvested in a 20-inch precipitation zone range from less than $\$ 0.20$ per 1,000 gallons for chemical treatments to over $\$ 6.00$ per 1,000 gallons for long-lasting materials such as concrete. The expected life, runoff efficiency, and yearly maintenance requirements are other factors which should be included when selecting the type of catchment surface to install. The water storage structure must also be matched to the catchment method to provide a satisfactory and complete water system.

\section{Literature Cited}

Burdass, W. J. 1975. Water harvesting for livestock in western Australia. Proc., Water Harvesting Symp., U.S. Dep. Agr., Agr. Res. Serv. ARS W-22, p. 8-26.

Cluff, C. B. 1967. Water harvesting plan for livestock or home. Prog. Agr. in Ariz. 19(3):6-8.

Chiarella, J. V., and W. H. Beck. 1975. Catchments on Indian lands in the Southwest. Proc., Water Harvesting Symp., U.S. Dep. Agr., Agr. Res. Serv. ARS W-22, p. 104-114.

Cooley, K. R., L. E. Myers, and G. W. Frasier. 1970. Lower cost water harvesting methods. In: Proc., Symp. on Interdisciplinary Aspects of Watershed Manage., Amer. Soc. Civil Eng. p. 27-41. 
Dedrick, A. R. 1973. Raintrap performance on the Fishlake National Forest. J. Range Manage. 26:9-12.

Dedrick, A. R. 1975. Storage systems for harvested water. In: Proc., Water Harvesting Symp., U.S. Dep. Agr., Agr. Res. Serv. ARS W-22, p. 175-191.

Dutt, G. R., and T. W. McCreary. 1975. Multipurpose salt treated water harvesting system. In: Proc., Water Harvesting Symp., U.S. Dep. Agr., Agr. Res. Serv. ARS W-22, p. 310-314.

Evans, C. E., D. A. Woolhiser, and F. Rauzi. 1975. Opportunity for harvesting water from and along highways in rangeland areas of Wyoming. In: Proc., Water Harvesting Symp., U.S. Dep. Agr., Agr. Res. Serv. ARS W-22, p. 293-301.

Fink, D. H., K. R. Cooley, and G. W. Frasier. 1973. Wax-treated soils for harvesting water. J. Range Manage. 26:396-398.

Frasier, G. W., and L. E. Myers. 1970. Protective spray coatings for water harvesting catchments. Trans. Amer. Soc. Agr. Eng. 13:292-294.

Frasier, G. W. 1975. Water harvesting for livestock, wildlife, and domestic use. In: Proc., Water Harvesting Symp., U.S. Dep. Agr., Agr. Res. Serv. ARS W-22, p. 40-49.
Frith, J. L. 1975. Design and construction of roaded catchments. In: Proc., Water Harvesting Symp., U.S. Dep. Agr., Agr. Res. Serv. ARS W-22, p. 122-127.

Gifford, G. F. 1973. Runoff and sediment yield from runoff plots on chained pinyon-juniper sites in Utah. J. Range Manage. 26:440-443.

Hollick, M. 1975. The design of roaded catchments for maximum runoff. In: Proc., Water Harvesting Symp., U.S. Dep. Agr., Agr. Res. Serv. ARS W-22, p. 201-220.

Lauritzen, C. W. 1967. Raintraps of steel. Utah Science, Sept., p. 79-81.

Lauritzen, C. W., and A. A. Thayer. 1966. Raintraps for intercepting and storing water for livestock. U.S. Dep. Agr., Agr. Res. Serv. Agr. Inform. Bull. 307.

Myers, L. E., and G. W. Frasier. 1969. Creating hydrophobic soil for water harvesting. J. Irrig. and Drain. Div., Amer. Soc. Civil Eng. Proc. 95(IR 1):43-54.

Myers, L. E., and G. W. Frasier. 1974. Asphalt-fiberglass for precipitation catchments. J. Range Manage. 27:12-14.

Reginato, R. J., F. S. Nakayama, and J. B. Miller. 1973. Reducing seepage from stock tanks with uncompacted sodium-treated soils. J. Soil and Water Conserv. 28:214-215. 